\title{
Roundness and matt degree of quartz grain surfaces in (fluvio-)glacial deposits of the Pomeranian Stage (Weichselian) in northeast Germany
}

\author{
Maria Górska-Zabielska \\ Institute of Geography, Jan Kochanowski University, ul. Świętokrzyska 15, 25-406 Kielce, Poland \\ e-mail: maria.gorska-zabielska@ujk.edu.pl
}

\begin{abstract}
Glacial tills and fluvioglacial sediments deposited by the ice-sheet during the Pomeranian Stage (Weichselian) in northeast Germany have been examined in terms of the degree of abrasion, rounding and frosting of quartz grain surfaces in order to determine the conditions and processes that occurred in the alimentation environment of the fine-grained material, as well as during transport. Strata in the glaciomarginal zone and the hinterland of the Pomeranian Stage in the area represent diverse lithofacies, but have similar textural features. These features illustrate mainly that a high-energy aquatic environment had reacted with glacial deposits prior to their inclusion into the ice mass and deposited in the area covered by the Odra lobe. The lack of regional diversification in the character of quartz grain surfaces in glacial deposits between the German part of the Odra lobe and the remainder of the area analysed is recorded solely in the morphological dimension, i.e. the outlet fragment of the ice-front's course, but not in textural features of the sediments.
\end{abstract}

Keywords: textural analysis, quartz grains, Pomeranian Stage, Mecklenburg-Vorpommern, Uckermark

\section{Introduction}

The character of quartz grain surfaces in the sandy fraction of Quaternary deposits plays an important role in their genetic and dynamic interpretation (Mycielska-Dowgiałło \& Woronko, 1998, 2001; Woronko, 2001). Textural features of these deposits allow conclusions to be drawn both on the depositional environment and on conditions prevailing in the alimentation areas. Quartz grains may obtain their shape and characteristic microstructures due to glacial crushing and abrasion independently (Haldorsen, 1981). Frost weathering may also be an important process that results in specific micro-relief of quartz grains and shape (Woronko, 2012).

The main goal of the present research was to identify selected textural features, i.e., roundness and matt degree of quartz grain surfaces derived from the glaciomarginal zone of the Pomeranian phase in northeast Germany. In addition, the re- lationship between the distinguished types and groups of quartz grains was examined. Attention was also paid to determination of conditions and processes that occurred within the alimentation area and during transport of particulate material during this phase of the last ice sheet. Lastly, the distinctiveness of Odra lobe deposits in comparison with coeval sediments of the marginal zone, but located further to the west, in Mecklenburg-Vorpommern has been considered.

\section{Study area}

The research was carried out at 14 sites (Fig. 1) situated within the glaciomarginal zone of the main Pomeranian Stage, its retreat phases and in the hinterland (Schulz, 1967; Liedtke, 1981; Bussemer et al., 1995). A total of 31 samples were analysed (Table 1); eight from trough cross-stratified 


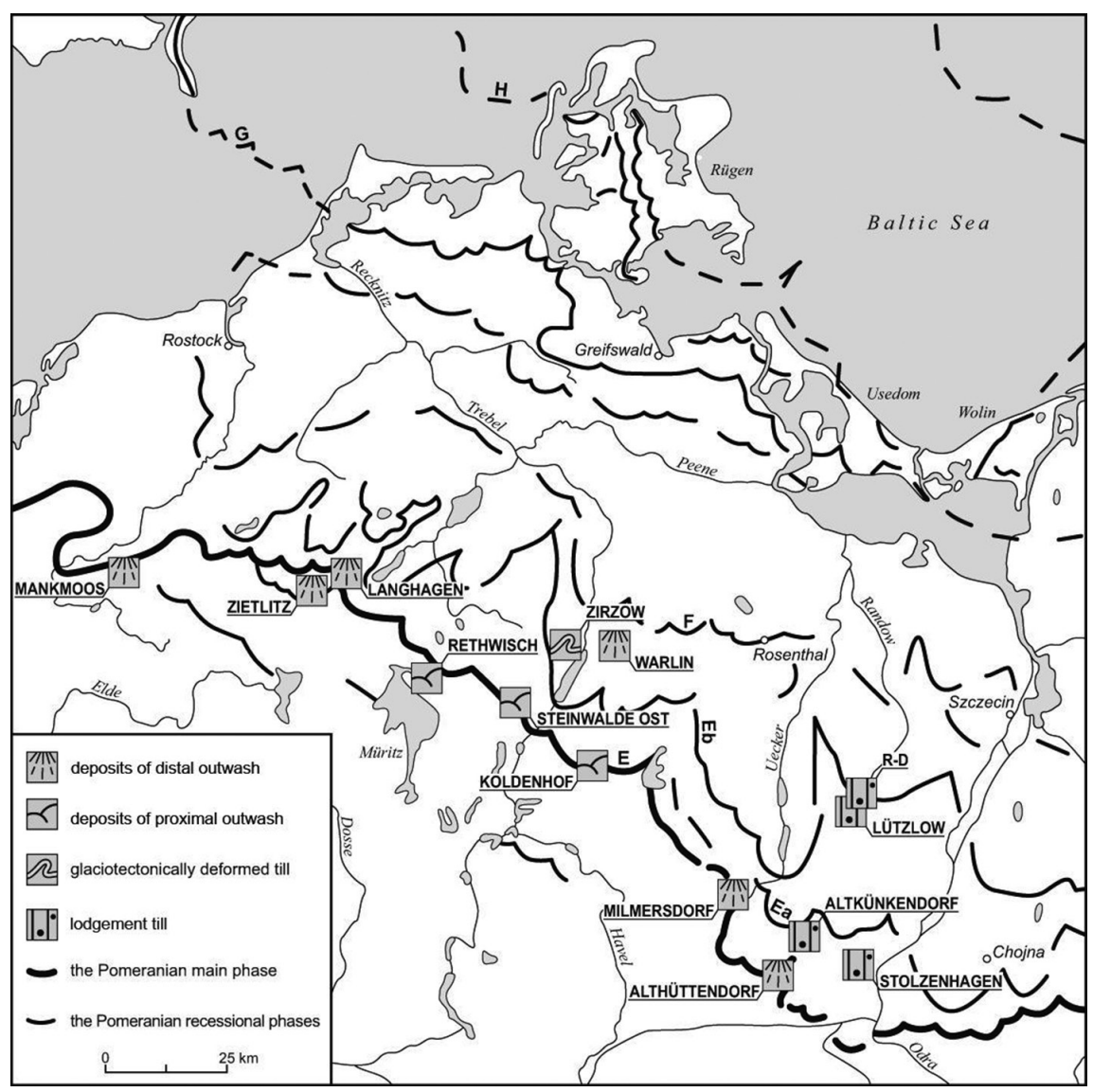

Fig. 1. Location of the study area, as plotted on major extension lines of the positional and recessional character of Weichselian glaciation in northeast Germany (after Liedtke, 1981; Bremer, 1994).

E - main Pomeranian Phase, Ea - Angermünde-Chojna Phase, Eb - Gerswalde-Mielęcin Phase, F - Rosenthaler Phase, G - Velgaster Phase, H - northern Rügen-Wolin Phase; R-D - Randow-Durchbruchstal Phase.

coarse sands, gravelly sands and sandy gravels (St, SGt, GSt) as well as tabular cross-stratified coarse sands, gravelly sands and sandy gravels $(S p, S G p$, GSp), typical of the proximal part of sandurs (Zieliński \& Pisarska-Jamroży, 2012). Thirteen samples represented horizontally stratified sandy deposits $(S h)$, typical of the central and distal parts of the outwash plains (Zieliński \& Pisarska-Jamroży, 2012). Ten samples were taken from the hinterland of the glaciomarginal zone, from a massive clayey-sandy diamicton $(\mathrm{Dm})$ with a matrix-supported framework. Detailed lithofacies characteristics and resultant conclusions on conditions of sedimentation of the deposits in the glaciomarginal zone and in the hinterland of the Pomeranian stage of the Weichselian in northeast Germany can be found in an earlier study, to which reference is made (Górska-Zabielska, 2008a).

Table 1. Depositional environments in Mecklenburg-Vorpommern and the Uckermark.

\begin{tabular}{|c|c|c|c|}
\hline Sedimentary environment & Study case & Sedimentary environment & Study case \\
\hline $\begin{array}{l}\text { Dis } \\
\text { distal part of an out-wash } \\
\text { plain }\end{array}$ & $\begin{array}{l}\text { Althüttendorf } \\
\text { Langhagen } \\
\text { Mankmoos } \\
\text { Milmersdorf } \\
\text { Warlin } \\
\text { Zietlitz }\end{array}$ & $\begin{array}{l}\text { proximal part of an out- } \\
\text { wash plain }\end{array}$ & $\begin{array}{l}\text { Koldenhof } \\
\text { Rethwisch Steinwalde Ost }\end{array}$ \\
\hline $\begin{array}{l}\text { active (deforming) ice- } \\
\text { sheet sole }\end{array}$ & Zirzow & $\begin{array}{l}\text { \.9 } \\
\text { active (depositing) ice- } \\
\text { sheet sole }\end{array}$ & $\begin{array}{l}\text { Altkünkendorf } \\
\text { Lützlow } \\
\text { Randow-Durchbruchstal } \\
\text { Stolzenhagen }\end{array}$ \\
\hline
\end{tabular}




\section{Methods}

Quartz grains of fractions 1.25-1.0 mm, 1.0-0.8 $\mathrm{mm}$ and $0.8-0.5 \mathrm{~mm}$ were analysed with regard to degree of abrasion, following Krygowski (1964), as well as by means of the morphoscopic method described by Cailleux (1942), and modified by Goździk (1980) and Mycielska-Dowgiałło \& Woronko (1998). The mechanical graniformameter of Krygowski (1964) and optical microscope Carl Zeiss Stemi DV4 were taken into consideration. In the analyses of evaluating the degree of the grain's abrasion according to Krygowski (1964) the value of the inclination angle of the inclined plane of graniformameter at which quartz grains had rolled down. Three types were singled out: a - untreated grains, extremely angular, rolling down at an inclination angle of the plate of more than $16^{\circ}, \beta$ - intermediate grains $\left(8-16^{\circ}\right)$ - as well as $\gamma$ - grains of good and very good abrasion, which had rolled down at an angle of $\leq 8^{\circ}$.

The same material was subjected to an analysis of rounding and frosting of quartz grain surfaces of the sandy fraction by Cailleux (1942), as modified by Goździk (1980) and Mycielska-Dowgiałło \& Woronko (1998). The following groups of grains were distinguished: NU - non-abraded, $\mathrm{RM}$ - rounded matt, EM/RM - partially rounded matt, i.e., intermediately rounded and matt only on edges and sharp points, RM/C - matt cracked, EL - well-rounded shiny, EM/EL - partially rounded shiny, EL/C - well-rounded, shiny, cracked as well as "other types". During the analysis, special attention was paid to the crushed/fractured grains (C), which may have originated in the subglacial deforming bed (Hart, 2006; Rose \& Hart, 2008) or in the proximal parts of the outwash plains among others (Woronko, 2001; Molén, 2014).

In order to mark out the alimentation areas for the glacial and fluvioglacial deposits of the sandy fraction occurring in the glaciomarginal zone and in the hinterland of the Pomeranian stage of the Weichselian in north-eastern Germany, the percentage of quartz grains in the deposit was defined. Due to its properties (resistant to both mechanical abrasion and chemical weathering), quartz may undergo selective enrichment in those deposits that are subject to repeated redeposition, for example in aeolian or channel environments (Mycielska-Dowgiałło, 2001; Woronko, 2001).

\section{Data presentation and analysis}

The deposits analysed have a relatively small differentiation, although the study was carried out on material of diverse lithofacies, originating in various sedimentatary environments typical of the glaciomarginal zone, beginning with fine-grained sand (distal part of sandur) through to gravelly sand and sandy gravel (proximal part). The research included also glacial deposits of the hinterland, i.e. tills. They showed also the lack of a clear differentiation of the chosen measurable textural features of these deposits, irrespective of the fact whether they came from material of the German part of the Odra lobe (the Uckermark) or of the glaciomarginal zone within the borders of Mecklenburg-Vorpommern.

\subsection{Quartz grain abrasion}

As seen from analysis of the degree of quartz grain abrasion, carried out with use of Krygowski's graniformameter (1964) (Table 2), the basic group consists of untreated quartz grains a (from $52.4 \%$ in the till of the $0.8-0.5 \mathrm{~mm}$ fraction in Mecklenburg-Vorpommern to $67.8 \%$ in the till in the Uckermark; Table 2). The quantity of this group is the highest, irrespective of lithofacies, fraction and region from which the material analysed originates. The average percentage of quartz grains of type a decreases along with the diminishing diameter of the analysed grain. This trend is maintained in the Uckermark and Mecklenburg-Vorpommern, both for sandy and clayey lithofacies (Table 2). Measured by the value of standard deviation, which is a measure of dispersion, the diversification of the number of quartz grains of type a between the analysed samples is increasingly more stable, alongside the decreasing fraction of the deposit.

Is it possible to discern a relationship between such a decreasing grain fraction and increasingly weaker influence of glacial crushing on these? Following Haldorsen (1981), ideas presented by Goździk and Mycielska-Dowgiałło (1982) on the constant character (or even conservation) of quartz grain surfaces in glacial environments must be rejected. In fact, this is the very environment in which quartz grains acquire their shape due to glacial comminution, i.e., crushing and abrasion (Haldorsen, 1981).

Quartz grains a may have resulted from frost weathering (Woronko, 2012), while frost-weathered (broken/crashed) quartz grains in periglacial environments (Woronko, 2012) had been incorporated into the advancing ice-mass. Together with the Scandinavian ice-sheet these sediments were transported as far south as the study area. The untreated quartz grains of type a may have originated also in high-energy fluvioglacial waters in the proximal parts of the outwashes (Woronko, 2001). 
Table 2. Results of analysis of rounding of quartz grains according to Krygowski (1964). Percentage content of quartz grains types $\alpha, \beta$ and $\gamma$ derived from fluvioglacial deposits and till of the main phase and the hinterland of the Pomeranian phase in Mecklenburg-Vorpommern and the Uckermark.

\begin{tabular}{|c|c|c|c|c|c|c|}
\hline & & fraction $[\mathrm{mm}]$ & parameter & a & $\beta$ & Y \\
\hline \multirow{12}{*}{ 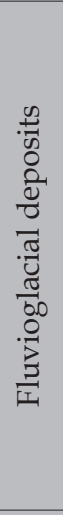 } & \multirow{6}{*}{ 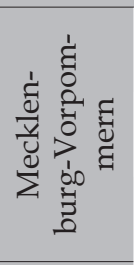 } & \multirow{2}{*}{$1.25-1.0$} & average [\%] & 67.2 & 30.6 & 2.2 \\
\hline & & & stand. dev. & 19.1 & 10.9 & 1.9 \\
\hline & & \multirow{2}{*}{$1.0-0.8$} & average [\%] & 63.0 & 32.2 & 4.9 \\
\hline & & & stand. dev. & 19.3 & 12.1 & 3.2 \\
\hline & & \multirow{2}{*}{$0.8-0.5$} & average [\%] & 59.3 & 37.0 & 3.7 \\
\hline & & & stand. dev. & 9.4 & 8.9 & 2.5 \\
\hline & \multirow{6}{*}{ 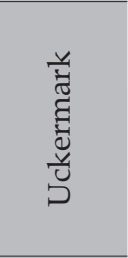 } & \multirow{2}{*}{$1.25-1.0$} & average [\%] & 62.5 & 35.9 & 1.6 \\
\hline & & & stand. dev. & 11.1 & 12.1 & 1.2 \\
\hline & & \multirow{2}{*}{$1.0-0.8$} & average [\%] & 56.3 & 37.8 & 6.0 \\
\hline & & & stand. dev. & 6.2 & 6.3 & 2.1 \\
\hline & & \multirow{2}{*}{$0.8-0.5$} & average [\%] & 53.1 & 41.0 & 5.9 \\
\hline & & & stand. dev. & 2.7 & 4.0 & 1.7 \\
\hline \multirow{12}{*}{ 洸 } & \multirow{6}{*}{ 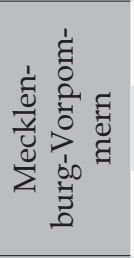 } & \multirow{2}{*}{$1.25-1.0$} & average [\%] & 66.8 & 30.9 & 2.4 \\
\hline & & & stand. dev. & 12.8 & 11.0 & 2.1 \\
\hline & & \multirow{2}{*}{$1.0-0.8$} & average [\%] & 64.9 & 30.8 & 4.4 \\
\hline & & & stand. dev. & 5.4 & 4.8 & 2.8 \\
\hline & & \multirow{2}{*}{$0.8-0.5$} & average [\%] & 52.4 & 41.3 & 6.4 \\
\hline & & & stand. dev. & 9.9 & 8.3 & 3.3 \\
\hline & \multirow{6}{*}{ 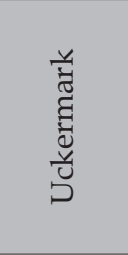 } & \multirow{2}{*}{$1.25-1.0$} & average [\%] & 67.8 & 30.1 & 2.1 \\
\hline & & & stand. dev. & 10.0 & 9.8 & 1.3 \\
\hline & & \multirow{2}{*}{$1.0-0.8$} & average [\%] & 64.4 & 31.9 & 3.7 \\
\hline & & & stand. dev. & 8.5 & 6.0 & 2.8 \\
\hline & & \multirow{2}{*}{$0.8-0.5$} & average [\%] & 58.3 & 36.6 & 5.2 \\
\hline & & & stand. dev. & 8.1 & 6.9 & 2.9 \\
\hline
\end{tabular}

There are between $30.6 \%$ (fluvioglacial deposits, $\varnothing 1.25-1.0 \mathrm{~mm}$, Mecklenburg-Vorpommern) to 41.3\% (glacial deposition, $\varnothing ~ 0.8-0.5$ mm, Mecklenburg-Vorpommern; Table 2) per grains of intermediate degree of abrasion $\beta$ among all the analysed quartz grains. Their percentage increases as grain size diminishes, while, compared to the a type, changes between fractions in $\beta$ type are smaller.

The least numerous $\gamma$ type consists of quartz grains of good and very good abrasion, the percentage of which does not exceed 6.4\% (glacial deposition, $\varnothing$ 0.8-0.5 mm, Mecklenburg-Vorpommern; Table 2). Quantitative changes between fractions differ depending of lithofacies. The largest percentage of quartz grains of the $\gamma$ type, which originated in fluvioglacial deposits, is noted in the $1.0-0.8 \mathrm{~mm}$ fraction. Both coarser and finer fractions contain fewer grains of this type (from $1.6 \%$ in the $1.25-1.0$ $\mathrm{mm}$ fraction to $5.9 \%$ in the $0.8-0.5 \mathrm{~mm}$ fraction in the Uckermark deposits). Quartz grains which originated in tills behave differently; in addition to a smaller diameter they are characterised by more extensive abrasion. According to Goździk \& Mycielska-Dowgiałło (1982) and Wright (1995), an increase in the percentage of quartz grains of the $\gamma$ type in finer fractions results from the conservation of this grain type in the glacial environment. In contrast, a decrease in the percentage of coarser quartz grains is a consequence of crushing to which larger quartz grains are subjected in this environment to a larger degree (Wright, 1995).

It follows from the analysis conducted that deposits of the glaciomarginal zone and hinterland of the Pomeranian Stage in northeast Germany reveal a close similarity in degree of abrasion of quartz grains in the sandy fraction.

\subsection{Roundness and matt degree of quartz grain surfaces}

The same quartz grains, examined following Krygowski's method (1964), were analysed to evaluate the degree of roundness and matt area of their surface (compare Cailleux, 1942; Goździk, 1980; Mycielska-Dowgiałło \& Woronko, 1998). The results obtained show (Table 3 - grey distinction) that, irrespective of lithofacies and sampling spot, the two commonest groups are partially rounded shiny grains (EM/EL) and well-rounded shiny ones 
(EL). These grains acquired a high degree of rounding and a smoothed surface in a high-energy aquatic environment (Mycielska-Dowgiałło \& Woronko, 1998).

While in the Uckermark material the differences between these groups are small (in the region of $10-15 \%)$, in the case of material originating from the sandy lithofacies of Mecklenburg-Vorpommern and in clayey lithofacies of all the entire study area, these even reach $60 \%$. It is worth noting that a smaller diameter of the quartz grain analysed is accompanied by a decrease in the percentage of partially rounded shiny grains (EM/EL) in favour of well-rounded shiny grains (EL). The trend is characteristic also of quartz grains of groups EM/ RM, NU and OTHER TYPES. In the quartz material, grains of typical aeolian origins (RM) make up a very small percentage. Only partially rounded matt grains (EM/RM) reach a maximum of $8.3 \%$ in deposits from the Uckermark. This group plays no role in the glacial material of the glaciomarginal zone of Mecklenburg-Vorpommern.

Links between abrasion type and degree of rounding and frosting of quartz grain surfaces have recently been noted by Goździk (2001), in that EL quartz grains often are disc shaped, which may influence the size of the group of grains of the $\gamma$ type. Grains of the EL type do not roll on Krygowski's graniformameter (1964), but slide down. Hence, although their percentage is high (Table 3; Fig. 2), grains of the $\gamma$ type belong to the least numerous group of quartz grains (Table 2 ) in the deposits analysed.

Among the cracked grains $(\mathrm{C})$, grains EL/C are more numerous. Cracked grains of the RM/C type are represented in individual fractions by no more than $0.5 \%$. In total, grains of the $C$ type are few; the highest average percentage of cracked grains $(\mathrm{EL} / \mathrm{C}=7.5 \%)$ is characteristic of fluvioglacial deposits of the 1.25-1.0 $\mathrm{mm}$ fraction, which originated in Mecklenburg-Vorpommern (Table 3; Fig. 2). The process of cracking/crushing of quartz grains may take place under various conditions. Crushing/ fracture is present in subglacial deforming beds (e.g., Whalley \& Krinsley, 1974; Haldorsen, 1981; Mahaney, 1990a, b; Hart, 2006; Rose \& Hart, 2008; Molén, 2014). The fluvioglacial environment also witnesses erosional processes. In the proximal parts of outwash plains, where, as a result of collision during the transport in saltation or basal traction, the character of abraded quartz grains develops (Woronko, 2001; Mahaney et al., 2001; Molén, 2014).

Where percentages of quartz grains in individual fractional ranges do not exceed $10 \%$, it would not appear that they were subjected to repeated redeposition, e.g., in an aeolian environment. Deposits influenced by abrasion in such an environment for a long time, i.e., by long-lasting air flow, are charac-

Table 3. Results of studies of quartz grain surfaces according to Cailleux (1942). Percentage content of respective groups of quartz grains derived from fluvioglacial sediments of the main phase and the hinterland and derived from till from the hinterland of the Pomeranian phase in Mecklenburg-Vorpommern and the Uckermark. The grey distinction shows that, irrespective of lithofacies and sample provenance, the two most numerous groups are partially rounded shiny grains (EM/EL) and well-rounded shiny ones (EL).

\begin{tabular}{|c|c|c|c|c|c|c|c|c|c|c|c|}
\hline \multirow{13}{*}{ 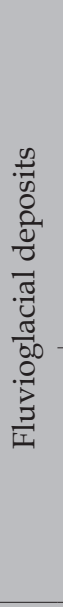 } & \multirow{7}{*}{ 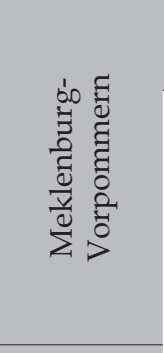 } & $\begin{array}{c}\text { fraction } \\
{[\mathrm{mm}]}\end{array}$ & parameter & $\begin{array}{l}\text { OTH- } \\
\text { ER }\end{array}$ & NU & $\mathrm{RM} / \mathrm{C}$ & EL/C & EL & $\begin{array}{c}\text { EM/ } \\
\text { EL }\end{array}$ & $\mathrm{RM}$ & $\begin{array}{r}\text { EM/ } \\
\text { RM }\end{array}$ \\
\hline & & \multirow{2}{*}{$1.25-1.0$} & average [\%] & 5.6 & 5.0 & 0.0 & 7.5 & 9.8 & 71.9 & 0.0 & 0.4 \\
\hline & & & stand. dev. & 4.6 & 4.4 & 0.0 & 4.4 & 5.4 & 6.2 & 0.0 & 0.7 \\
\hline & & \multirow{2}{*}{$1.0-0.8$} & average [\%] & 7.6 & 3.9 & 0.0 & 6.8 & 12.7 & 68.1 & 0.0 & 0.9 \\
\hline & & & stand. dev. & 5.7 & 2.4 & 0.0 & 4.4 & 8.0 & 8.1 & 0.0 & 1.9 \\
\hline & & \multirow{2}{*}{$0.8-0.5$} & average [\%] & 4.7 & 3.2 & 0.0 & 5.5 & 18.7 & 66.5 & 0.2 & 1.2 \\
\hline & & & stand. dev. & 3.2 & 3.3 & 0.0 & 2.9 & 7.9 & 8.6 & 1.0 & 1.6 \\
\hline & \multirow{6}{*}{ 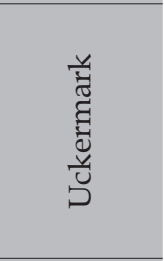 } & \multirow{2}{*}{$1.25-1.0$} & average [\%] & 11.5 & 9.1 & 0.0 & 3.7 & 21.8 & 45.3 & 0.8 & 7.9 \\
\hline & & & stand. dev. & 9.4 & 4.9 & 0.0 & 1.3 & 13.1 & 6.7 & 0.5 & 2.7 \\
\hline & & \multirow{2}{*}{$1.0-0.8$} & average [\%] & 5.9 & 7.4 & 0.5 & 5.7 & 31.0 & 39.7 & 1.5 & 8.3 \\
\hline & & & stand. dev. & 4.2 & 4.2 & 1.1 & 2.6 & 7.2 & 4.7 & 0.9 & 3.2 \\
\hline & & \multirow{2}{*}{$0.8-0.5$} & average [\%] & 6.3 & 5.5 & 1.0 & 3.4 & 33.5 & 45.4 & 1.0 & 4.0 \\
\hline & & & stand. dev. & 5.1 & 3.2 & 1.4 & 1.6 & 2.4 & 3.5 & 0.8 & 1.7 \\
\hline \multirow{6}{*}{$\underset{\exists}{ }$} & \multirow{6}{*}{ 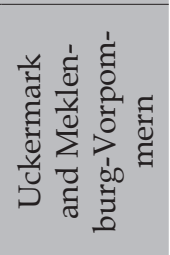 } & \multirow{2}{*}{$1.25-1.0$} & average [\%] & 5.3 & 4.5 & 0.1 & 6.6 & 10.2 & 67.0 & 1.3 & 4.9 \\
\hline & & & stand. dev. & 3.5 & 3.6 & 0.3 & 2.4 & 5.2 & 11.0 & 2.3 & 6.2 \\
\hline & & \multirow{2}{*}{$1.0-0.8$} & average [\%] & 3.2 & 3.1 & 0.3 & 6.1 & 19.8 & 64.1 & 0.7 & 2.7 \\
\hline & & & stand. dev. & 2.2 & 1.8 & 0.9 & 1.7 & 13.0 & 16.6 & 1.4 & 5.2 \\
\hline & & \multirow{2}{*}{$0.8-0.5$} & average [\%] & 2.5 & 2.4 & 0.1 & 6.6 & 26.6 & 58.4 & 0.8 & 2.4 \\
\hline & & & stand. dev. & 2.7 & 1.5 & 0.3 & 2.6 & 12.3 & 14.5 & 1.3 & 3.2 \\
\hline
\end{tabular}



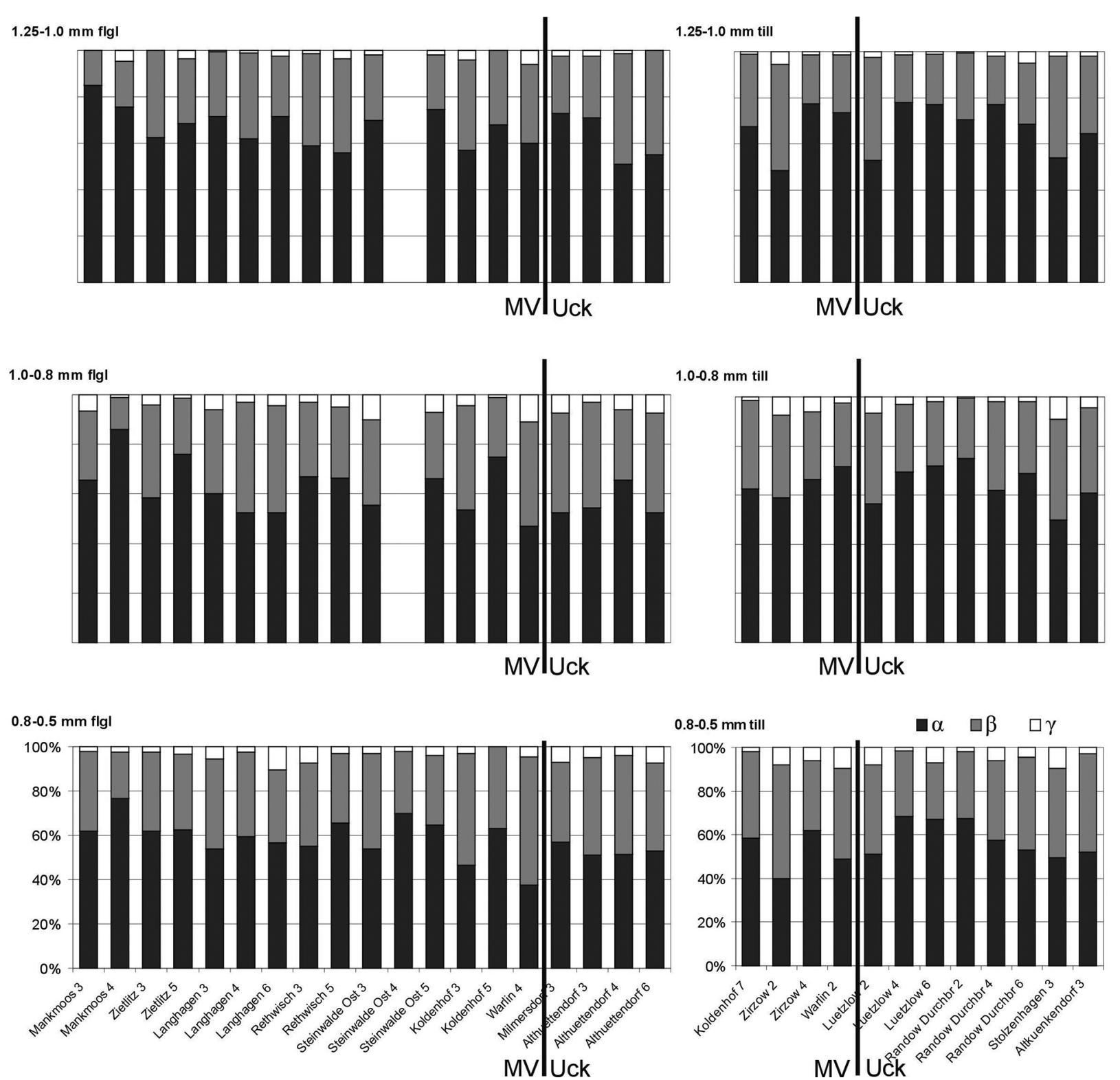

Fig. 2. Results of analysis of roundness of quartz grains according to Krygowski (1964). Percentage content of quartz grains of types $\alpha, \beta$ and $\gamma$ derived from fluvioglacial deposits (flgl) and till (gl) of the main phase and the hinterland of the Pomeranian phase in Mecklenburg-Vorpommern (MV) and the Uckermark (Uck).

terised by a high percentage of quartz grains, about 90-92\% (Kamińska et al., 1986). Sand-fraction deposits of the glaciomarginal zone of the Pomeranian Stage of Mecklenburg-Vorpommern had not undergone aeolian processes earlier, i.e., prior to their accumulation in the fluvioglacial environment.

The very high percentage of EL and EM/EL grains, as well as EL/C types indicates that they originated in an aquatic environment, inclusive of a high-energy beach setting during the Paleogene-Neogene to the north of the study area (Schulz, 2003). Rock outcrops situated in the littoral zone at that time appear today on Rügen Island and have also been recorded from the bottom of the western and southern Baltic Sea (Górska-Zabielska, 2008b). The former existence of other outcrops of such rocks, which due to erosion have now disappeared completely, cannot be ruled out (Górska, 2000). The ice-sheet advancing from the north-north-east moved over outcrops of these rocks and included them into the material transported.

\section{Discussion}

The sandy-gravelly lithofacies and tills in the glaciomarginal zone and in the hinterland of the main phase of the Pomeranian Stage and of reces- 
sive stages in northeast Germany, were studied in order to evaluate the degree of abrasion and rounding of quartz grain surfaces of the sandy fraction. These analyses served to determine the conditions and processes that took place in the alimentation environment of fine-grained material and during transport. Valuable data have been obtained for the reconstruction of environmental conditions under which the transport and deposition of sediments occurred.

The abrasion of quartz grain surfaces reveals a close similarity between glacial and fluvioglacial deposits, despite the fact that the material examined represents diversified lithofacies of the glaciomarginal zone and the hinterland. The material does not show any distinct differences of textural features either, despite the extensive distribution of sites studied. The localities furthest removed from each other - Mankmoos and Stolzenhagen - are around $180 \mathrm{~km}$ apart, in a straight line (Fig. 1).

Textural features of sandy deposits in the study area provide evidence of a high-energy aquatic environment in which quartz grains acquired surface features typical of such a setting. Mainly the results of rounding and frosting are convincing in this respect. Irrespective of lithofacies and provenance area, partially rounded shiny grains (EM/EL) are the commonest type (Table 3 ). Their average percentage decreases, coupled with a decreasing grain diameter in favour of well-rounded shiny grains (EL), the percentage of which increases even twofold between the 1.25-2.0 and 0.8-0.5 mm fractions.

A similar average percentage of groups of quartz grains in sandy fractions of the Pomeranian Stage in the study area indicates that the untreated grains a are partially rounded shiny grains (EM/EL) and, to a lesser degree, well-rounded shiny grains (EL) which acquired features of rounding and frosting in a high-energy aquatic environment (Mycielska-Dowgiałło \& Woronko, 1998). Taken together, both groups constitute more than half, and often three-quarters, of all the quartz grains of the deposits analysed.

The lack of regional differentiation of the character of quartz grain surfaces in examined deposits between the German part of the Odra lobe and the remainder of the study area may suggest that the diversified dynamics of the marginal zone of the ice-sheet during the Pomeranian Stage were recorded only in the morphological dimension, i.e., the outlet fragment of the ice-front's course. So far, the available data do not allow any conclusion to be drawn on different mechanisms that functioned inside the Odra glacial stream, as they are not reflected in unique textural features. Complementary textural studies of quartz grains, carried out in the glacial deposits that originated in the Polish part of the Odra lobe as well as further north-east along the glaciomarginal zone of the Pomeranian Stage in Poland, appear to confirm this regularity (Górska, 2005, 2006; Górska-Zabielska, 2007).

Glacial deposits of the marginal zone of the Pomeranian Stage of Mecklenburg-Vorpommern and the Uckermark had their alimentation areas on the Baltic Shield and on the bottom of the Baltic Sea. Strata exposed in Paleogene- Neogene littoral zones, nowadays found along the German Baltic coastline, must also have been glacially eroded, although to a much lesser degree. Transport and deposition of these sediments occurred in an aquatic environment. All textural features analysed document their fluvioglacial character.

The lack of textural diversification of the deposits analysed is here documented for the first time in the study area. Previous papers on the question of a glacial surge (e.g., Dyke \& Morris, 1988; Stokes \& Clark, 1999, 2001; Kjær et al., 2003; Kasprzak, 1988, 2003) have not discussed the different regime of an individualised ice stream as recorded in textural features of the deposits.

Here, it is worth adding that petrographic analysis of the medium-grained gravelly fraction and a study of indicator erratics in the coarse-grained gravelly fraction of glacial deposits in the glaciomarginal zone of the Pomeranian Stage in northeast Germany and northwest Poland bring very different statement on this issue (Górska-Zabielska, 2008c). The gravels of the Odra lobe differ petrographically from those occurring to the west and east from this outlet part of the glaciomarginal zone which originated in the Upper Pleni-Weichselian.

\section{Conclusions}

Three main conclusions can be drawn from the present study with respect to quartz grains derived from lithologically diversified sediments which represent facies of the glaciomarginal zone and the hinterland of the Pomeranian Stage of northeast Germany. Sediments of both proximal and distal parts of an outwash plain were sampled within the glaciomarginal zone. In the hinterland of the Pomeranian Stage, mainly till was studied. In addition, one site documenting the proximal part of an outwash plain and another one representing glaciotectonically deformed till were investigated in detail.

There are no differences between quartz grains examined following Krygowski (1964). Irrespective 
of lithofacies, fraction and provenance area, the basic group consists of untreated quartz grains $a$, i.e., extremely angular grains, rolling down at inclination angles of $>16^{\circ}$ (Krygowski, 1964).

Analyses of rounding and frosting of quartz grain surfaces of sandy fraction according to Cailleux (1942; subsequently modified by Goździk, 1980 and Mycielska-Dowgiałło \& Woronko, 1998), indicate a close similarity between glacial and fluvioglacial deposits. Irrespective of lithofacies and sample provenance, two main groups have been noted: partially rounded shiny grains (EM/EL) and well-rounded shiny ones (EL). These grains acquired a high degree of rounding and a smoothed surface in a high-energy aquatic environment.

The glacial deposits of the marginal zone of the Pomeranian Stage of Mecklenburg-Vorpommern and the Uckermark most likely had their alimentation areas on the Baltic Shield and on the bottom of the Baltic Sea. For some an origin from Paleogene-Neogene littoral zones, occurring at present along the Baltic coast of Germany, cannot be ruled out.

\section{Acknowledgements}

I thank everyone who assisted during fieldwork in Mecklenburg-Vorpommern and in the Uckermark. Analyses of the abrasion of quartz grains were performed by Mirosława Malinowska-Limanówka (Adam Mickiewicz University, Poznań), of frosting and rounding by Małgorzata Gościńska, who also drew Fig. 1. Barbara Woronko (University of Warsaw) offered numerous interpretational remarks and pieces of advice. I am extremely grateful for their reliable co-operation. Fieldwork and laboratory analyses were paid for by a DAAD A/99/06440 grant, while supplementary research was conducted within the framework of the KBN 6P04E 01521 research project.

\section{References}

Bremer, F., 1994. Geologische Karte von Mecklenburg-Vorpommern. Übersichtskarte 1 : 500000 - Oberfläche. Geologisches Landesamt MV, Schwerin.

Bussemer, S., Gärtner, P. \& Schlaak, N., 1995. Pomeranian terminal moraine near Schiffmühle. [In:] W. Schirmer (Ed.): Vol. 1. Regional field trips. International Union for Quaternary Research, XIV Intern. Congress INQUA, Berlin 3-10.08.1995, 1223-1224.

Cailleux, A., 1942. Les action eoliennes periglaciaires en Europe. Mémoires de la Société géologique de France, 41 pp.

Dyke, A.S. \& Morris, T.F., 1988. Drumlin fields, dispersal trains and ice streams in Arctic Canada. Canadian Geographer 32, 86-90.
Górska, M., 2000. Wybrane właściwości petrograficzne vistuliańskich moren dennych środkowej i zachodniej Wielkopolski oraz ich znaczenie dla oceny dynamiki ostatniego lądolodu [Some petrographical features of Vistulian lodgement till in the central and southern Wielkopolska Lowland and their significance towards estimating the dynamics of the last ice sheet]. Prace Komisji Geograficzno-Geologicznej PTPN 28, 145 pp.

Górska, M., 2005. Sediments of the Odra Lobe in the light of selected textural and mineral analyses. Quaestiones Geographicae 24, 29-49.

Górska, M., 2006. Textur und Schwerminerale der Geschiebemergel und der fluvioglazialen Sedimente des Pommerschen Stadiums des Weichselian im nordöstlichen Deutschland. [Summary: Texture and the heavy minerals of the till and the fluvioglacial deposits of the Vistulian Pomeranian Phase in the north-eastern Germany]. Zeitschrift für Geomorphologie 50, 321-345.

Górska-Zabielska, M., 2007. Lob Odry - morfologia a tekstura osadów [Odra lobe - morphology versus sediments texture]. Przeglad Geologiczny 55, 197-198.

Górska-Zabielska, M., 2008a. Conditions of sedimentation in the Weichselian glaciomarginal zone of northeastern Germany. Geological Quaterly 52, 157-168.

Górska-Zabielska, M., 2008b. Obszary macierzyste skandynawskich eratyków przewodnich osadów ostatniego zlodowacenia północno-zachodniej Polski i północno-wschodnich Niemiec [Source regions of the Scandinavian indicator erratics of glacial deposits of the northern Poland]. Geologos 14, 177-194.

Górska-Zabielska, M., 2008c. Fennoskandzkie obszary alimentacyjne osadów akumulacji glacjalnej i glacjofluwialnej lobu Odry [Fennoscandian source areas of glacial and glaciofluvial deposits of the Odra lobe (north-western Poland and north-eastern Germany)]. Adam Mickiewicz University Press, Poznań, 78, 330 pp.

Goździk, J., 1980. Zastosowanie morfometrii i graniformametrii do badań osadów w kopalni węgla brunatnego Bełchatów [Usage of morphometry and graniformametry in the investigations of the sediments in the brown coal mine in Bełchatów]. Studia Regionalne IV (IX). PWN Warszawa-Łódź, 101-114.

Goździk, J., 2001. O zależności między pomiarami graniformametrycznymi a stopniem zaokrąglenia ziarn [The relationship between the graniformametric measurements and the degree of grain roundness]. [In:] E. Mycielska-Dowgiałło (Ed.): Eolizacja osadów jako wskaźnik stratygraficzny czwartorzędu [The record of aeolian processes on sediments as an indicator of the Quaternary stratigraphy]. Wydział Geografii i Studiów Regionalnych Uniwersytetu Warszawskiego, 21-31.

Goździk, J. \& Mycielska-Dowgiałło, E., 1982. Badania wpływu niektórych procesów geologicznych na przekształcenia powierzchni ziarn kwarcowych [Investigation of the effect of certain geological processes on the transformation of the surface of quartz grains]. Przeglad Geologiczny 54, 219-241.

Haldersen, S., 1981. Grain-size distribution of subglacial till and its relation to glacial crushing and abrasion. Boreas 10, 91-105. 
Hart, J., 2006. An investigation of subglacial processes at the microscale from Briksdalsbreen, Norway. Sedimentology 53, 125-146.

Kamińska, R., Konecka-Betley, K. \& Mycielska-Dowgiałło, E., 1986. The Liszyno dune in the Vistula valley (east of Płock). Biuletyn Peryglacjalny 31, 141-162.

Kasprzak, L., 1988. Dyferencjacja mechanizmów formowania stref marginalnych faz leszczyńskiej i poznańskiej ostatniego zlodowacenia na Nizinie Wielkopolskiej [Differentiation mechanisms of formation of glacial marginal zones of the Leszno and the Poznan Phases of the last glaciation in the Wielkopolska Lowland]. PAN, Dokumentacja Geograficzna 5-6, 159 pp.

Kasprzak, L., 2003. Model sedymentacji lądolodu vistuliańskiego na Nizinie Wielkopolskiej [Model of sedimentation of the Vistulian ice sheet in the Wielkopolska Lowland]. Wyd. Nauk. UAM, Seria Geografia 66, 216 pp.

Kjær, K.H., Houmark-Nielsen, M. \& Richardt, N., 2003. Ice-flow patterns and dispersal of erratics at the southerwestern margin of the last Scandinavian Ice Sheet: signature of palaeo-ice streams. Boreas 32, 130-148.

Krygowski, B., 1964. Graniformametria mechaniczna. Teoria, zastosowanie [Mechanical graniformametry. Theory, application]. Prace Komisji Geograficzno-Geologicznej PTPN 2, 4, 112 pp.

Liedtke, H., 1981. Die nordischen Vereisungen in Mitteleuropa. Forschungen zur deutschen Landeskunde. Band 204, 308 pp.

Mahaney, W.C., 1990a. Macrofabrics and quartz microstructures confirm glacial origin of Sunnybrook drift in the Lake Ontario basin. Geology 18, 145-148.

Mahaney, W.C., 1990b. Glacially-crushed quartz grains in late Quaternary deposits in the Virunga Mountains, Rwanda - indicators of wind transport from the north? Boreas 19, 81-89.

Mahaney, W.C., Stewart, A. \& Kalm, V., 2001. Quantification of SEM microtextures useful in sedimentary environment discrimination. Boreas 30, 165-171.

Molén, M.O., 2014. A simple method to classify diamicts by scanning electron microscope from surface microtexture. Sedimentology 61, 2010-2041.

Mycielska-Dowgiałło, E. \& Woronko, B., 1998. Analiza obtoczenia i zmatowienia powierzchni ziarn kwarcowych frakcji piaszczystej i jej wartość interpretacyjna [Analysis of roundness and matt surface of the quartz grains and its interpretive value]. Przeglad Geologiczny 46, 1275-1281.

Mycielska-Dowgiałło, E. \& Woronko, B., 2001. Wybrane cechy sedymentologiczne osadów ułatwiające ich podział stratygraficzny, na przykładzie otworów Galumin 1, Kozły K-1, Niksowizna i Olszewo Węgorzewskie [Selected sedimentological characteristics of sediments which help their stratigraphic division, on the basis of boreholes Galumin 1, Kozły K-1, Niksowizna and Olszewo Węgorzewskie]. [In:] E. Mycielska-Dowgiałło (Ed.): Eolizacja osadów jako wskaźnik stratygraficzny czwartorzedu [The record of aeolian pro- cesses on sediments as an indicator of the Quaternary stratigraphy]. Wydział Geografii i Studiów Regionalnych, Warsaw University, 43-58.

Mycielska-Dowgiałło, E., 2001. Wpływ warunków klimatycznych na cechy strukturalne i teksturalne osadów mineralnych. [In:] A. Karczewski \& Z. Zwoliński (Eds): Funkcjonowanie geoekosystemów w zróżnicowanych warunkach morfoklimatycznych. Monitoring, ochrona, edukacja [Geoecosystems functioning in different morphoclimatic conditions. Monitoring, Protection, Education]. Poznań, 377-394.

Rose, R.K. \& Hart, J.K., 2008. Subglacial comminution in the deforming bed: Inferences from SEM analysis. Sedimentary Geology 203, 87-97.

Schulz, W., 1967. Abriß der Quartärstratigraphie Mecklenburgs. Archiv der Freunde der Naturgeschichte in Mecklenburg 13, 99-119.

Schulz, W., 2003. Geologischer Führer für den norddeutschen Geschiebesammler. CW Verlagsgruppe, Schwerin, 508 pp.

Stokes, C.R. \& Clark, C.D., 1999. Geomorphological criteria for identifying Pleistocene ice streams. Annals of Glaciology 28, 67-75.

Stokes, C.R. \& Clark, C.D., 2001. Palaeo-ice streams. Quaternary Science Reviews 20, 1437-1457.

Whalley, W.B. \& Krinsley, D.H., 1974. A scanning electron microscope study of surface textures of quartz grains from glacial environments. Sedimentology 21, 87-105.

Woronko, B., 2001. Znaczenie analizy obtoczenia i zmatowienia powierzchni ziarn kwarcowych frakcji piaszczystej w interpretacji genetycznej osadów czwartorzędowych [The importance of the analysis of roundness and matt surface of quartz grains of the sandy fraction in the genetic interpretation of Quaternary sediments]. [In:] E. Mycielska-Dowgiałło (Ed.): Eolizacja osadów jako wskaźnik stratygraficzny czwartorzędu [The record of aeolian processes on sediments as an indicator of the Quaternary stratigraphy]. Wydział Geografii i Studiów Regionalnych, Warsaw University, 33-38.

Woronko, B., 2012. Micromorphology of quartz grains as a tool in the reconstruction of periglacial environment. [In:] P. Churski (Ed.): Contemporary Issues in Polish Geography, 111-131.

Wright, J.S., 1995. Glacial comminution of quartz sand grains and the production of loessic silt: a simulation study. Quaternary Science Reviews 14, 669-680.

Zieliński, T. \& Pisarska-Jamroży, M., 2012. Jakie cechy litologiczne warto kodować, a jakie nie? [Which features of deposits should be included in a code and which not?]. Przeglad Geologiczny 60, 387-397.

Manuscript submitted 10 January 2015 Revision accepted 29 April 2015 